\title{
Diagnosing relationships with spatial distance: An empirical test of a clinical principle
}

\author{
D. Russell Crane \\ Brigham Young University - Provo
}

David C. Dollahite

Brigham Young University - Provo, david_dollahite@byu.edu

William Griffin

University of Virginia

Vincent L. Taylor

Our Lady of the Lake University

Follow this and additional works at: https://scholarsarchive.byu.edu/facpub

Part of the Other Social and Behavioral Sciences Commons

\section{Original Publication Citation}

Crane, D. R., Dollahite, D. C., Griffin, W., \& Taylor, V. L. (1987). Diagnosing relationships with spatial distance: An empirical test of clinical principle. Journal of Marital and Family Therapy, 13(3), 307-310.

\section{BYU ScholarsArchive Citation}

Crane, D. Russell; Dollahite, David C.; Griffin, William; and Taylor, Vincent L., "Diagnosing relationships with spatial distance: An empirical test of a clinical principle" (1987). Faculty Publications. 5015.

https://scholarsarchive.byu.edu/facpub/5015

This Peer-Reviewed Article is brought to you for free and open access by BYU ScholarsArchive. It has been accepted for inclusion in Faculty Publications by an authorized administrator of BYU ScholarsArchive. For more information, please contact ellen_amatangelo@byu.edu. 


\title{
BRIEF REPORTS
}

\section{DIAGNOSING RELATIONSHIPS WITH SPATIAL DISTANCE: AN EMPIRICAL TEST OF A CLINICAL PRINCIPLE*}

\author{
D. Russell Crane \\ David C. Dollahite \\ Brigham Young University \\ William Griffin \\ University of Virginia \\ Vincent L. Taylor \\ Our Lady of the Lake University
}

Several family systems therapists have discussed the value of observing families' spatial relationships as an aid in diagnosing family structure and processes. For example, Haley (1976) notes that: "When the family members seat themselves, sometimes the organization of the family is clarified" (p. 18). Minuchin (1974) also discusses the same idea when he writes: "When the family sits down, the family therapist should pay attention to how they position themselves. Often their placement can give him some hunches about family affiliations" (p. 207). The general idea behind this concept is that families often reveal a good deal about themselves in the way they arrange themselves spatially with one another.

This idea of spatial arrangements is strikingly similar to the notion of "personal space." Personal space has been defined as "the area individual humans actively maintain around themselves into which others cannot intrude without arousing discomfort" (Hayduk, 1978, p. 118). Personal space has been extensively researched and has been found to be smallest among close friends, greater among acquaintances and greatest among strangers (Edwards, 1972). One could anticipate, therefore, that relationships would vary in spatial arrangement based on friendship or liking between the persons involved. Indeed, such an idea seems central to the diagnostic value of spatial relationships in families. That is, family members who like each other should arrange themselves closer spatially than family members who do not.

The purpose of this study was to investigate the idea of spatial arrangement as it applies to one component of families-married couples. Couples were chosen as a first step in the study of the diagnostic value of spatial relationships in family therapy.

*Research support for this article was provided partially by the College of Family, Home, and Social Sciences of Brigham Young University, Provo, UT.

D. Russell Crane, PhD, is Associate Professor, Marriage and Family Therapy, Department of Family Sciences, Brigham Young University, Provo, U'T 84602.

David C. Dollahite, MS, is a doctoral student in the Family Social Science Program, University of Minnesota, St. Paul, MN 55108.

William Griffin, PhD, is an NIMH Postdoctoral Fellow, Department of Psychology NI-25, University of Washington, Seattle, WA 98195.

Vincent L. Taylor, PhD, is Assistant Professor, Marriage and Family Therapy, Department of Education and Clinical Studies, Our Lady of the Lake University, San Antonio, TX 78285. 
There have been only a few investigations of personal space as it relates to married couples. In one study, personal space was found to be smaller for husband/wife dyads than for same sex and opposite sex dyads (Hill, Blackman \& Crane, 1982). In another study with a small sample of 24 couples, personal space was found to relate to several aspects of marital quality (Crane \& Griffin, 1983). Personal space also effectively differentiated between distressed and nondistressed couples. The present study attempts to determine further if interpersonal distance is a useful method of diagnosing relationship conflict.

\section{METHOD}

\section{Subjects}

A total of 108 couples participated in this study. Couples were volunteers for a "marital interaction study" or were clients referred by practicum students. The volunteer and client samples were compared on age, number of children, level of education, length of marriage and number of previous marriages; no significant differences were found. Consequently, both samples were combined for analysis where appropriate.

\section{Measures}

The A reas of Change (AC) questionnaire is a 34-item self-report instrument designed to assess the amount of change desired by each spouse. A total score of 15 discriminates distressed from nondistressed couples (Birchler, Weiss \& Vincent, 1975).

The Locke-Wallace Marital Adjustment Test (MAT) is a questionnaire widely used to assess overall marital quality. The MAT score of 100 has been used extensively to distinguish distressed from nondistressed couples (e.g., Griffin \& Crane, 1986).

The Marital Status Inventory (MSI) is a scale of divorce potential. Scores range from 0-14, with higher scores indicating greater instability. Crane, Newfield, and Armstrong (1984) provide validity and reliability data on the MSI.

The Couples' Space Measure is a measure frequently used in the study of personal space (e.g., Crane \& Griffin, 1983; Hill, et al., 1982; Pedersen, 1973) and it has been recommended as the best measure of personal space in Hayduks' $(1978,1983)$ reviews of the field.

\section{Procedure}

As each couple arrived for testing, they were greeted by a research assistant. They were shown to an assessment room, and the couples' space measure was taken. This was done by having the couples stand some distance apart and then approach each other and stop at a "comfortable conversation distance." The distance between the spouses' nearest toes was then measured in inches. The couple was then given a packet of questionnaires to be completed independently before leaving.

\section{RESULTS}

The couples' space measure correlated with the husbands' MAT and MSI in the expected direction $(r=-.19$ and $.19 p<.05$, respectively). That is, the lower the husbands' marital adjustment, and the more steps he had taken towards divorce, the larger the distance between the spouses.

In terms of general conflict, the couples' space measure correlated significantly in the predicted direction $(r=.24, p<.01)$ with their AC scores. Increased conflict in the marriage was associated with increased distance between the spouses.

The couples' space measure was also able to reliably differentiate between distressed and nondistressed spouses. Couples were classified as distressed by a couple mean of 
less than 100 on the MAT and a couple score of more than 15 on the AC. In other words, to be classified as distressed, both partners had to be unhappy in their marriage (MAT) and they had to have considerable unresolved conflict in their relationship (AC). The mean distance in inches between distressed spouses $(M=14.8, S D=11.4)$ was greater than for nondistressed spouses $(M=11.4, S D=7.2 ; t(76)=-1.64, p<.05,1$-tail).

\section{DISCUSSION}

The results of the study suggest that couples' space can be used to identify conflicted marital relationships. Couples' space correlated with all three of the marital assessment instruments in the predicted direction. Couples' space was also effective in differentiating between distressed and nondistressed couples.

The results of the current study, however, show that the relationship between couples' space and marital quality is more complicated than previously thought. In the Crane and Griffin (1983) study with 24 couples, couples' space correlated in the expected direction with the couples' marital adjustment (couple mean MAT; $r=-.37, p<.01$ ). In the current study with a larger sample, couples' space was related only to the husbands' marital adjustment scores.

The correlational results are consistent, but not powerful; however, one should not expect a high correlation from such methodologically diverse measurements. For example, Margolin (1978) reported a low correlation (.02) between a self-report and a behavioral coding instrument, yet high correlations between two self-report and two behavioral measurements (.43 and .77 , respectively). The measures used in this study are quite different (self-report and behavioral) and one should not anticipate large correlations between them. What is apparent, however, is that a clear relationship exists between distance and relationship quality. Further, this relationship can be identified even when correlating a self-report and a behavioral measure. Such a finding indicates a powerful relationship. This conclusion is even more evident when one considers that distressed couples, on the average, maintain a $23 \%$ greater distance between spouses than do nondistressed couples. Such a difference argues for the existence of a strong relationship between interpersonal distance and relationship conflict.

These data also indicate that the relationship satisfaction of the husbands probably determines the amount of distance between the spouses. It seems that husbands may have more influence than wives regarding interpersonal distance in marriage. It may be true that wives who complain of husbands who are "distant" may be exactly right. Further research is underway to examine this hypothesis more closely.

Overall, these results lend empirical support to the idea of observing interpersonal distance to diagnose relationships. What has been proposed, based on clinical experience and judgment, has been supported empirically.

\section{REFERENCES}

Birchler, G. R., Weiss, R. L. \& Vincent, T. P. (1975). Multimethod analysis of social reinforcement exchange between maritally distressed and non-distressed spouse and stranger dyads. Journal of Personality \& Social Psychology, 31, 349-360.

Crane, D. R. \& Griffin, W. (1983). Personal space: An objective measure of marital quality. Journal of Marital and Family Therapy, 9, 325-327.

Crane, D. R., Newfield, N. \& Armstrong, D. (1984). Predicting divorce at marital therapy intake: Wives' distress and the marital status inventory. Journal of Marital and Family Therapy, 10, 305-312. 
Edwards, D. J. A. (1972). Approaching the unfamiliar: A study of human interaction distances. Journal of Behavioral Science, 1, 249-250.

Griffin, W. \& Crane, D.R. (1986). Nonverbal reciprocity in nondistressed marital partners: An examination of base rate change. Journal of Marital and Family Therapy, 12, 301-309.

Haley, J. (1976). Problem-solving therapy. San Francisco, CA: Jossey-Bass, Inc.

Hayduk, L. A. (1978). Personal space: An evaluative and orienting overview. Psychological Bulletin, $85,117-134$.

Hayduk, L. A. (1983). Personal space: Where we now stand. Psychological Bulletin, 94, 293-335.

Hill, R. D., Blackman, R. E. \& Crane, D. R. (1982). The effect of the marital relationship on personal space orientation in married couples. Journal of Social Psychology, 118, 23-28.

Margolin, G. (1978). Relationships among marital assessment procedures: A correlational study. Journal of Consulting and Clinical Psychology, 51, 920-931.

Minuchin, S. (1974). Families and family therapy. Cambridge, MA: Harvard University Press.

Pedersen, D. M. (1973). Development of a personal space measure. Psychological Reports, 32, 527535. 